\title{
Comparative Analysis of Free Radical Scavenging Potential of Pyrroloquinoline Quinone (PQQ) and Several Plants Extracts by in-vitro Methods
}

\section{Kumar $\mathbf{N}^{*}$ and Kar A}

School of life Sciences, Devi Ahilya University, Takshashila Campus, Indore, India

Research Article

Volume 2 Issue 1

Received Date: June 21, 2017

Published Date: July 11, 2017

*Corresponding author: Narendra Kumar, School of life Sciences, Devi Ahilya University, Takshashila Campus, Indore, India, Email: narendrakumar93@gmail.com

\section{Abstract}

In-vitro lipid peroxidation (LPO) was induced by ferrous sulphate $\left(\mathrm{FeSO}_{4}\right)$, hydrogen peroxide $\left(\mathrm{H}_{2} \mathrm{O}_{2}\right)$ and carbon tetrachloride $\left(\mathrm{CCl}_{4}\right)$ and then the effects of five different concentrations $(10,20,40,80$ and $160 \mu \mathrm{M})$ of pyrroloquinoline quinone (PQQ) were evaluated in liver, the major target organ of a drug. A comparison was made with the effects of some known antioxidative plant extracts and vitamin C. For this different concentrations of $\mathrm{PQQ}$, vitamin $\mathrm{C}$ and herbal extracts of Annona squamosa (AS), Rauvolfia serpentina (RS), Withania somnifera (WS), Commiphora mukul (CM), Syzygium cumini (SC) and Gymnema sylvestre (GS) were considered and examined through different in-vitro antioxidant potential assays such as Azino-bisethylbenzothiazoline-6-sulphonic acid (ABTS) scavenging assay; Diphenylpicrylhydrazyl (DPPH) scavenging assay; Metal $\left(\mathrm{FeCl}_{2}\right)$ chelating assay; Hydrogen peroxide $\left(\mathrm{H}_{2} \mathrm{O}_{2}\right)$ scavenging assay and Superoxide (SO) radical scavenging assay. While $\mathrm{FeSO}_{4}, \mathrm{H}_{2} \mathrm{O}_{2}$ and $\mathrm{CCl}_{4}$ markedly enhanced the hepatic LPO; simultaneous administration of PQQ reduced it in a concentration dependent manner. This effect was observed in all three, $\mathrm{FeSO}_{4}, \mathrm{H}_{2} \mathrm{O}_{2}$ and $\mathrm{CCl}_{4}$ induced hepatic LPO. Out of five different concentrations of PQQ $20 \mu \mathrm{M}$ and $80 \mu \mathrm{M}$ showed the maximum inhibition in LPO, suggesting its beneficial/antioxidative activity. While comparing the antioxidative potential of PQQ with some known antioxidative herbal extracts and vitamin $\mathrm{C}$, the test drug exhibited highest antioxidative activity in all the above free radical scavenging assays, further consolidating very high antioxidative potential of $P Q Q$. PQQ exhibited better antioxidative potential than some known plant extracts. Therefore, its therapeutic use may prove to be advantageous in ameliorating oxidative stress associated diseases.

Keywords: PQQ; TBARS; ABTS; DPPH; SO; $\mathrm{H}_{2} \mathrm{O}_{2}$; Metal chelating assay

\section{Introduction}

It is now well known that the lipid peroxidation (LPO) is induced by free radicals and reactive oxygen species that are generated continuously in the physiological processes of all living systems [1] and if not scavenged or converted to less reactive forms, they attack the unsaturated bond of the macromolecules, ultimately damaging the cell [2]. It is a growing belief that most of the common health problems are associated with 


\section{Advances in Pharmacology and Clinical Trials}

enhanced LPO [3-7]. Few investigations are there on the antiperoxidative effects of some plant extracts involving both in vivo and in vitro studies [8-11]. Although pyrroloquinoline quinone (PQQ) is believed to be an antioxidant, it has not been affirmed. In order to consolidate its antioxidative potential, in the present investigation, for the first time an attempt has been made to study the hitherto unknown in vitro antiperoxidative effects of $\mathrm{PQQ}$, using some antioxidative agents.

It is well established that iron is involved in lipid peroxidation. As ferrous ions precipitate the formation of oxygen radicals and initiate peroxidative process, ferrous sulphate $\left(\mathrm{FeSO}_{4}\right)$ is often used to induce tissue LPO [12]. Similarly, hydrogen peroxide $\left(\mathrm{H}_{2} \mathrm{O}_{2}\right)$ and carbon tetrachloride $\left(\mathrm{CCl}_{4}\right)$ have also been used to induce tissue LPO $[13,14]$. Therefore, in this investigation the LPO was induced by $\mathrm{FeSO}_{4}, \mathrm{H}_{2} \mathrm{O}_{2}$ and $\mathrm{CCl}_{4}$ the efficacy tests were made considering inhibition of LPO in hepatic tissues.

The antiperoxidative effects of some plant extracts were also correlated with free radical scavenging activity of PQQ. Phytochemical investigations have shown the presence of alkaloids, saponins, D-mannitol, betulic acid and $\beta$-sitosterol in some plants [15]. Because phytochemicals such as polyphenols, flavonoids, anthraquinones are known to exhibit antioxidative properties [16-18], plant extracts are believed to act as antioxidant. PQQ is also considered as antioxidant, but its antioxidant potential has not been consolidated. In-fact, its in vitro antioxidative potential is still unclear. In the present study we have investigated their antioxidative potential in vitro and compared the same with some known plant extracts, considering vitamin C (Vit.C) as a standard.

\section{Materials and methods}

\section{Animal}

Standard ethical guidelines of the committee for the purpose of control and supervision of experiments on animals (CPCSEA), Ministry of Environment, Forest and Climate Change, New Delhi, Govt. of India. (Reg. No. 779/Po/Ere/S/03/CPCSEA) were followed. Before starting the investigation, the approval of the departmental ethical committee for handling and maintenance for experimental animals was also obtained.

\section{Chemicals}

Azino-bisethylbenzothiazoline-6-sulphonic acid (ABTS); Diphenylpicrylhydrazyl (DPPH) was obtained from SIGMA, USA. Thio-barbeuteric acid (TBA) was procured from Hi-media pvt. Ltd. $\mathrm{FeCl}_{2}, \mathrm{FeSO}_{4}, \mathrm{H}_{2} \mathrm{O}_{2}, \mathrm{CCl}_{4}$ and all other chemicals (analytical grades) were obtained from Merck India Ltd., Mumbai, India. While $\mathrm{FeSO}_{4}$ was dissolved in distilled water, $\mathrm{H}_{2} \mathrm{O}_{2}$ and $\mathrm{CCl}_{4}$ were dissolved in phosphate buffer saline and dimethyl sulfoxide (DMSO), respectively, as used earlier [11,19].

\section{Preparation of the herbal extracts}

Officinal parts of six different herbs (Table 1) which were reported to act as antioxidant $[7,9]$ were collected from the local market (Indore, India),dried then pulverized in an electrical grinder to obtain a free flowing dry powder.

\begin{tabular}{|c|c|c|c|}
\hline \multicolumn{5}{|c|}{ (Common name) } \\
\hline Scientific name & English & Hindi & \multirow{2}{*}{ Family } \\
\hline Annona squamosa & (Sugar apple) & (Sitafal) & Annonaceae \\
\hline Rauvolfia serpentina & (Snake root) & (Sarpagandha) & Apocynaceae \\
\hline Withania somnifera & (Winter cherry) & (Ashwagandha) & Solanaceae \\
\hline Commiphora mukul & (Gum gugul) & (Guggul) & Burseraceae \\
\hline Syzygium cumini & (Black plum) & (Jambul) & Myrtaceae \\
\hline Gymnema sylvestre & (Australian cowplant) & (Gurmar) & Apocynaceae \\
\hline
\end{tabular}

Table 1: Botanical species were used for the comparative study.

100 grams of powder of each plant part was extracted with $400 \mathrm{ml}$ of ethyl alcohol (70\%) at the RT, incubated overnight and then filtered through Whatman filter paper no.1. The dried filtrate (at $37^{\circ} \mathrm{C}$ ) was stored for future use. Each extract powder was dissolved in double distilled water (DW) for final experimentation. 


\section{Advances in Pharmacology and Clinical Trials}

\section{Preparation of Liver Homogenate}

For this adult male rat were sacrificed after anaesthetizing with mild chloroform. Liver from each animal was taken out immediately, blood clots were removed, washed in phosphate buffered saline (PBS), cut into small pieces and then homogenized in $10 \%$ ice cold PBS. Different experiments were performed with the prepared liver homogenates and at the end LPO was measured using the standardized protocol followed in our laboratory $[9,11]$.

\section{Induction of LPO}

LPO was studied using the standardized protocol routinely followed in our laboratory $[9,11]$. In brief, to 1 $\mathrm{ml}$ of liver homogenate, $100 \mu \mathrm{FeSO} \mathrm{F}_{4} / \mathrm{H}_{2} \mathrm{O}_{2}$ respectively and $\mathrm{CCl}_{4}$ (20 $\mu \mathrm{l}$ for $\mathrm{CCl}_{4}$ case) were added; while in control set, the same amount of DW was mixed. Then the reaction mixture was incubated at $37^{\circ} \mathrm{C}$ for $1 \mathrm{~h}$, following which 2 $\mathrm{ml}$ TCA $(10 \%)$ was added to the mixture and the samples were centrifuged at $3000 \mathrm{rpm}$ for 5 minutes. $2 \mathrm{ml}$ supernatant was taken out and to it $1 \mathrm{ml}$ TBA was added followed by boiling in water bath for $45 \mathrm{~min}$. After cooling in running water OD was taken at $532 \mathrm{~nm}$ as routinely done in our laboratory $[7,11]$.

\section{$\mathrm{LPO}$ in $\mathrm{FeSO}_{4}$ System}

In three sets of test tubes (in triplicate), each containing $1 \mathrm{ml}$ of liver homogenate, three different concentrations ( 1 or 5 or $10 \mathrm{mM}$ ) of $\mathrm{FeSO}_{4}$ were taken. These concentrations of $\mathrm{FeSO}_{4}$ were taken from earlier report [11]. A control set was also run in which all materials other than $\mathrm{FeSO}_{4}$ were added. All the tubes were processed for the estimation of LPO by TBA reaction method as described above. Considering the effective concentration of $\mathrm{FeSO}_{4}$ that showed maximum increase in hepatic LPO, antiperoxidative effect of the different concentrations of PQQ was evaluated. Five concentrations of PQQ were considered in this experiment that was 10 , $20,40,80$ and $160 \mu \mathrm{M}$. All five concentrations were taken in triplicate. Simultaneously a set of drug control tubes was processed that contained all the materials except PQQ.

LPO was induced by addition of $100 \mu \mathrm{l}$ of $5 \mathrm{mM} \mathrm{FeSO}_{4}$ in the reaction mixture containing PBS and chopped tissue and by incubating at $37^{\circ} \mathrm{C}$ for 2 hour [7]. In another set liver slices were incubated with $100 \mu \mathrm{l}$ of $5 \mathrm{mM} \mathrm{FeSO}_{4}$ along with one of the concentrations $(10,20,40,80$ and $160 \mu \mathrm{M}$ ) of PQQ dissolved in DW. After $2 \mathrm{~h}$, each homogenate mixture of chopped liver was centrifuged at $800 \mathrm{~g}$ and the supernatant was used to measure LPO by
TBA reaction method, as followed earlier [11,20]. A control set was run in which all materials other than $\mathrm{FeSO}_{4}$ or PQQ were added.

\section{LPO in $\mathrm{H}_{2} \mathrm{O}_{2}$ and $\mathrm{CCl}_{4}$ System}

Similar procedure, as mentioned above was repeated with $\mathrm{H}_{2} \mathrm{O}_{2}$ or $\mathrm{CCl}_{4}$. In three sets of test tubes (each in triplicate) containing $1 \mathrm{ml}$ of liver homogenate, three different concentrations $(40,80$ and $160 \mathrm{mM})$ of $\mathrm{H}_{2} \mathrm{O}_{2}$ or three different concentrations $(10,20$ and $40 \mu \mathrm{l})$ of $\mathrm{CCl}_{4}$ were taken. These concentrations of $\mathrm{H}_{2} \mathrm{O}_{2}$ and $\mathrm{CCl}_{4}$ were taken from earlier report $[7,11]$. A control set was also run in which all materials other than $\mathrm{H}_{2} \mathrm{O}_{2}$ or $\mathrm{CCl}_{4}$ were added. All the tubes were processed for the estimation of LPO by TBA reaction method as described above.

Considering the most effective concentration of $\mathrm{H}_{2} \mathrm{O}_{2}$ or $\mathrm{CCl}_{4}$ that showed maximum increase in hepatic LPO, antiperoxidative effects of $\mathrm{PQQ}$ was evaluated. Five concentrations of $\mathrm{PQQ}$ were considered in this experiment that was $10,20,40,80$ and $160 \mu \mathrm{M}$. All five concentrations were taken in triplicate; a set of drug control tubes was also processed that contained all the materials except PQQ. LPO was estimated with similar protocol as mentioned earlier. In the $\mathrm{H}_{2} \mathrm{O}_{2}$ system, the reaction mixture contained $400 \mathrm{mg}$ of the chopped liver tissues in $3.9 \mathrm{ml}$ of PBS, $100 \mu \mathrm{l}$ of $80 \mathrm{mM} \mathrm{H}_{2} \mathrm{O}_{2}$ and PQQ of one of the five concentrations, $10,20,40,80$ and $160 \mu \mathrm{M}$ (each in triplicates). The mixture was incubated at $37{ }^{\circ} \mathrm{C}$ for $2 \mathrm{~h}$. Following the addition of trichloroacetic acid (TCA) and TBA the optical density (OD) was measured at $532 \mathrm{~nm}$ [20]. In case of $\mathrm{CCl}_{4}$ system also the reaction mixture contained $400 \mathrm{mg}$ of the chopped liver tissues in $3.9 \mathrm{ml}$ of PBS, $20 \mu \mathrm{CCl}_{4}(1: 4$ in DMSO, v/v) and PQQ of one of the five concentrations, $10,20,40,80$ and $160 \mu \mathrm{M}$ (each in triplicates). Following the incubation at $37^{\circ} \mathrm{C}$ and the addition of TCA and TBA, OD was measured at $532 \mathrm{~nm}$ [21].

\section{Antioxidant Activity Determinations}

\section{Azino-bisethylbenzothiazoline-6-sulphonic acid (ABTS) Scavenging Assay:}

For ABTS assay, the procedure followed was of Arnao et al. [22], with some modifications. The stock solutions included $7.4 \mathrm{mM}$ ABTS solution and $2.6 \mathrm{mM}$ potassium per sulfate solution. The working solution was then prepared by mixing the two stock solutions in equal quantities and allowing them to react for $12 \mathrm{~h}$ at room temperature in the dark. The solution was then diluted by mixing $1 \mathrm{~mL}$ ABTS solution with $60 \mathrm{ml}$. Then the absorbance was taken at $734 \mathrm{~nm}$ using the 


\section{Advances in Pharmacology and Clinical Trials}

spectrophotometer. The assay was performed at least in triplicate. Controls containing $990 \mu \mathrm{l}$ of PBS, to replace ABTS, were used to measure absorbance of the extract themselves. The assay relies on the antioxidant capability of the samples to inhibit the oxidation of ABTS to ABTS •+ radical cat-ion. The percentage of ABTS scavenging was calculated as:

$\%$ ABTS scavenging $=[(\mathrm{AC}-\mathrm{AS}) / \mathrm{AC}] \times 100$

Where, AC is the absorbance of the control and AS is the absorbance of the sample.

Diphenylpicrylhydrazyl (DPPH) scavenging assay: The effect of crude extracts on the DPPH radicals was estimated using the method of Yamaguchi et al., [23]. An aliquot of crude extract ( $30 \mu \mathrm{l})$ and glutathione (GSH) $(0.5$ $\mathrm{mg} / \mathrm{ml}, 30 \mu \mathrm{l})$ were mixed with $100 \mathrm{mM}$ Tris- $\mathrm{HCl}$ buffer $(120 \mu \mathrm{l}, \mathrm{pH}$ 7.4) and then with $150 \mu \mathrm{l}$ of the DPPH in ethanol to a final concentration of $250 \mu \mathrm{M}$. The mixture was shaken vigorously and left to stand at room temperature for $20 \mathrm{~min}$ in the dark. The absorbance at $517 \mathrm{~nm}$ of the reaction solution was measured spectrophometrically. The percentage of DPPH decolourization of the sample was calculated according to the following equation:

$\%$ decolourization $=[(\mathrm{AC}-\mathrm{AS}) / \mathrm{AC}] \times 100$

Where, AC is the absorbance of the control and AS is the absorbance of the sample.

Metal chelating activity: The chelating of ferrous ions by extracts was estimated by using the method of Ebrahimzadeh et al., [24]. For iron chelating activity assay, the reaction mixture containing $1 \mathrm{ml}$ 0Phenanthroline, $2 \mathrm{ml}$ ferric chloride and $2 \mathrm{ml}$ of test extract at various concentrations ranging from 2 to 1000 $\mu \mathrm{g} / \mathrm{ml}$ in a final volume of $5 \mathrm{ml}$ was incubated for 10 minutes at ambient temperature. The absorbance at 510 $\mathrm{nm}$ was recorded. Ascorbic acid was added instead of extract and absorbance obtained was taken as equivalent to $100 \%$ reduction of all ferric ions. Blank was carried out without drug. Metal chelating activity was calculated following the formula:

$\%$ Metal chelating activity $=[(\mathrm{AC}-\mathrm{AS}) / \mathrm{AC}] \times 100$

Where, AC is the absorbance of the control and AS is the absorbance of the sample.

Hydrogen peroxide $\left(\mathrm{H}_{2} \mathrm{O}_{2}\right)$ scavenging assay: Hydrogen peroxide scavenging activity was determined according to the method of Ruch et al. [25]. A solution of $\mathrm{H}_{2} \mathrm{O}_{2}(40 \mathrm{mM})$ was prepared in phosphate buffer ( $\mathrm{pH}$ 7.4). Test extract $(100 \mu \mathrm{g} / \mathrm{ml})$ in distilled water was added to a $\mathrm{H}_{2} \mathrm{O}_{2}$ solution $(0.6 \mathrm{~mL}, 40 \mathrm{mM})$ and absorbance at $230 \mathrm{~nm}$ was determined 10 minutes later against a blank solution containing the phosphate buffer without $\mathrm{H}_{2} \mathrm{O}_{2}$. The percentage of $\mathrm{H}_{2} \mathrm{O}_{2}$ scavenging was calculated as:

$$
\% \text { Scavenged }\left[\mathrm{H}_{2} \mathrm{O}_{2}\right]=[(\mathrm{AC}-\mathrm{AS}) / \mathrm{AC}] \times 100
$$

Where AC is the absorbance of the control and AS is the absorbance of the sample.

Superoxide (SO) radical scavenging assay: The superoxide radical scavenging activity was studied by using the method of Liu, et al. [26]. $100 \mu \mathrm{l}$ Riboflavin solution $(20 \mu \mathrm{g}), 200 \mu \mathrm{l}$ EDTA solution $(12 \mathrm{mM}), 200 \mu \mathrm{l}$ methanol and $100 \mu \mathrm{l}$ NBT (Nitro-blue tetrazolium) solution $(0.1 \mathrm{mg})$ were mixed in test tube and reaction mixture was diluted up to $3 \mathrm{ml}$ with phosphate buffer (50 $\mathrm{mM}$ ). The absorbance of solution was measured at 590 $\mathrm{nm}$ in a spectrophotometer (Shimadzu, UV-1800, Japan). First time, the percentage scavenging activity was calculated using the following formula,

$$
\% \text { Scavenged }[\mathrm{SO}]=[(\mathrm{AC}-\mathrm{AS}) / \mathrm{AC}] \times 100
$$

Where, AS is the absorbance of the test (With extract) and $\mathrm{AC}$ is the absorbance of the control (without extract).

\section{Statistical Analysis}

Data are expressed as mean \pm SE. Statistical analysis was done by using analysis of variance (ANOVA) followed by student's t-test and $\mathrm{P}$ values of $5 \%$ and less were considered to be significant.

\section{Results}

Following the incubation of liver homogenates with 1, 5 and $10 \mathrm{mM}$ of $\mathrm{FeSO}_{4}$ a significant increase in LPO $(\mathrm{P}<0.001$ to all) was observed. However, the maximum \% of LPO increased was observed at $5 \mathrm{mM}$ of $\mathrm{FeSO}_{4}$ (i.e. $394 \%$ ). When considering this effective concentration of $\mathrm{FeSO}_{4}$ that showed maximum increase in hepatic LPO (i.e $5 \mathrm{mM}$ ), antiperoxidative effect of the test compound (PQQ) was evaluated. $\mathrm{FeSO}_{4}(5 \mathrm{mM})$ markedly enhanced hepatic LPO $(\mathrm{P}<0.001)$, following the incubation with five different concentrations of $\mathrm{PQQ}$, (i.e 10, 20, 40, 80 and $160 \mu \mathrm{M})$ could inhibit the $\mathrm{FeSO}_{4}(5 \mathrm{mM})$ induced LPO in all. However, the maximum decrease was observed at 20 $\mu \mathrm{M}(\mathrm{P}<0.001$, Figure 1 ; as compared to the average value of $\mathrm{FeSO}_{4}$ control tubes). The percentage decrease in LPO of different concentrations of PQQ $(10,20,40,80$, and 160 $\mu \mathrm{M})$ were $50 \%, 67 \%, 58 \%, 60 \%$ and $60 \%$ respectively (Figure 1). 


\section{Advances in Pharmacology and Clinical Trials}

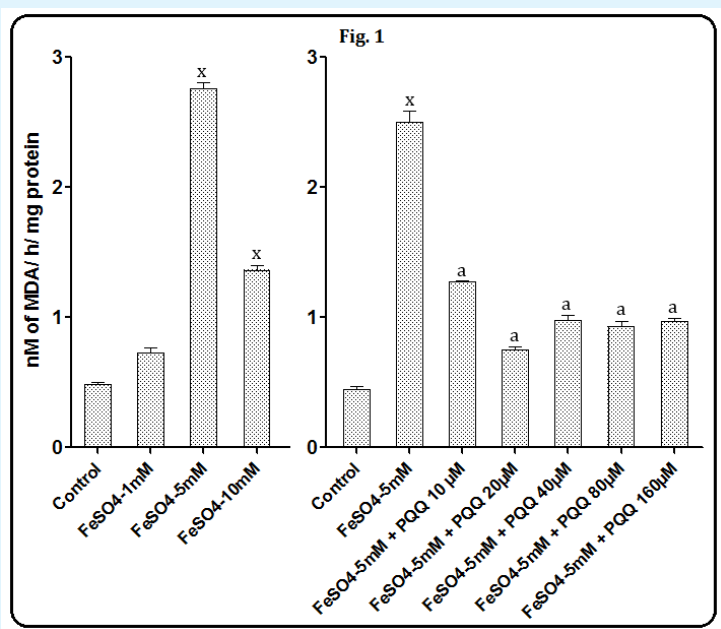

Figure 1: Effects of PQQ at 10, 20, 40, 80 and $160 \mu \mathrm{M}$ on FeSO4-induced hepatic LPO. Data are mean \pm SEM $(n=3)$. $\mathrm{x}, \mathrm{P}<0.001$ compared to the respective control values. $\mathrm{a}$, $\mathrm{P}<0.001$ as compared to the respective FeSO 4 treated value.

Incubation of rat liver slices with different concentrations of $\mathrm{H}_{2} \mathrm{O}_{2}(40,80$ and $160 \mathrm{mM})$ resulted in a significant increase in hepatic LPO. However, maximum the percent increase i.e. $363 \%$ was observed at $80 \mathrm{mM}$. Considering this effective concentration of $\mathrm{H}_{2} \mathrm{O}_{2}$ to induce hepatic LPO, i.e $80 \mathrm{mM}$, when incubation with any of the five different concentrations of PQQ, i.e 10, 20, 40, 80 and $160 \mu \mathrm{M}$ was done, the maximum decrease was observed at $80 \mu \mathrm{M}(\mathrm{P}<0.001$, as compared to the average value of $\mathrm{H}_{2} \mathrm{O}_{2}$ control tubes. The percent decreases in LPO of different concentrations of PQQ $(10,20,40,80,160 \mu \mathrm{M})$ were $3 \%, 2 \%, 24 \%, 62 \%$ and $57 \%$ respectively (Figure 2).

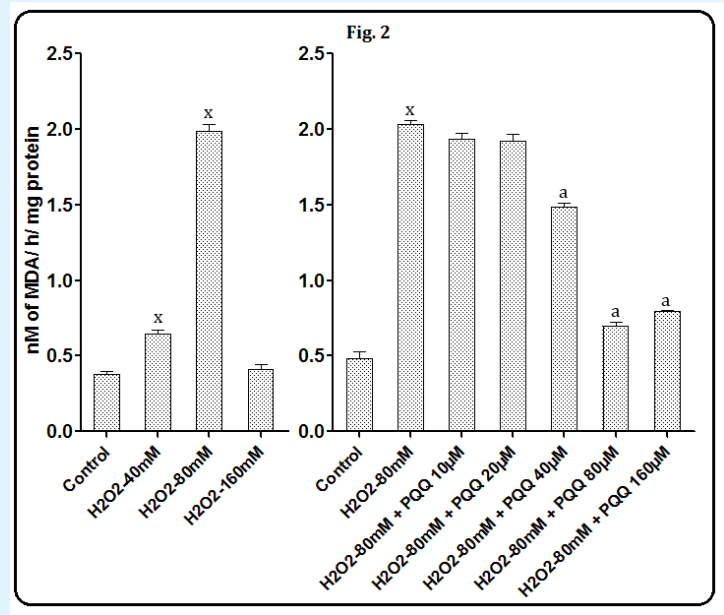

Figure 2: Effects of PQQ at 10, 20, 40, 80 and $160 \mu \mathrm{M}$ on $\mathrm{H}_{2} \mathrm{O}_{2}$-induced hepatic LPO. Data are mean \pm SEM $(n=3) . x$,
$\mathrm{P}<0.001$ compared to the respective control values. $\mathrm{a}, \mathrm{P}<$ 0.001 as compared to the respective $\mathrm{H}_{2} \mathrm{O}_{2}$ treated value.

With respect to incubation of liver homogenates with $\mathrm{CCl}_{4}(10,20$ and $40 \mu \mathrm{l})$, a significant increase in LPO $(\mathrm{P}<$ 0.001 to all) was observed in all three concentrations (40\%, 407\% and 175\% respectively). When, considering the effective concentration of $\mathrm{CCl}_{4}$ that showed maximum increase in hepatic LPO (i.e $20 \mu \mathrm{l}$ ), antiperoxidative effects of the test compound (PQQ) was evaluated, $\mathrm{CCl}_{4}(20 \mu \mathrm{l})$ markedly enhanced hepatic LPO $(\mathrm{P}<0.001)$. However, following the incubation with five different concentrations of PQQ, i.e 10, 20, 40, 80 and $160 \mu \mathrm{M}$, the maximum decrease was observed at $80 \mu \mathrm{M}(\mathrm{P}<0.001$, as compared to the average value of $\mathrm{CCl}_{4}$ control tubes). The other concentrations were also able to inhibit LPO but slightly less as compared to that of $80 \mu \mathrm{M}$. The percentage decreases in LPO of different concentrations of PQQ (10, $20,40,80,160 \mu \mathrm{M}$ ) were $25 \%, 36 \%, 38 \%, 62 \%$ and $61 \%$ respectively (Figure 3 ).

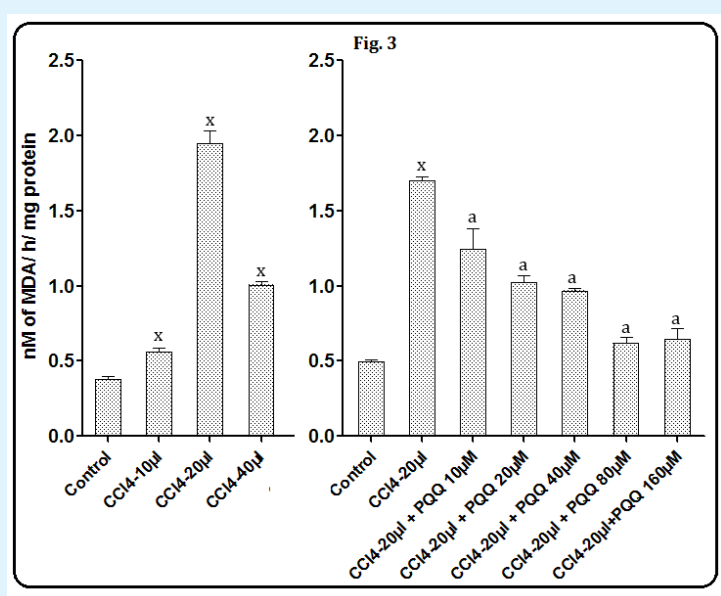

Figure 3: Effects of PQQ at 10, 20, 40, 80 and $160 \mu \mathrm{M}$ on $\mathrm{CCl}_{4}$-induced hepatic LPO. Data are mean \pm SEM $(n=3) . x$, $\mathrm{P}<0.001$ compared to the respective control values. ${ }^{\mathrm{a}} \mathrm{P}<$ 0.001 as compared to the respective $\mathrm{CCl}_{4}$ treated value.

Thus, concentration dependent effects were observed with PQQ that inhibited $\mathrm{FeSO}_{4} / \mathrm{CCl}_{4} / \mathrm{H}_{2} \mathrm{O}_{2}$-induced hepatic LPO. After incubating liver homogenates with prestandardized concentrations of $\mathrm{FeSO}_{4}(5 \mathrm{mM}), \mathrm{CCl}_{4}(20 \mu \mathrm{l})$ and $\mathrm{H}_{2} \mathrm{O}_{2}$ (80 mM); there was an increase in LPO. However, out of five different concentrations of PQQ, only $20 \mu \mathrm{M}, 80 \mu \mathrm{M}$ and $80 \mu \mathrm{M}$ were found to inhibit maximally the $\mathrm{FeSO}_{4} / \mathrm{CCl}_{4} / \mathrm{H}_{2} \mathrm{O}_{2}$-induced tissue LPO respectively.

With respect to different antioxidant assays using PQQ, plant extracts and vitamin $\mathrm{C}$; the results indicated that all six herbal extracts were effective in the radical scavenging 


\section{Advances in Pharmacology and Clinical Trials}

assays. However, differential effects were found in PQQ and the test plant extracts. Interestingly PQQ exhibited better effects as compared to the plant extracts and Vit C.

ABTS assay: The ABTS radical scavenging assay revealed that all three different concentrations of PQQ $(25,50$, and $100 \mu \mathrm{g} / \mathrm{ml}$ ) showed a marked scavenging of ABTS radicals
(78.0\%, 82.04\% and 88.05\%, respectively); which are significantly $(\mathrm{P}<0.001$ in all doses) higher as compared to that of plant extracts and Vit C. While RS \& SC also showed the significant $(\mathrm{P}<0.001)$ higher radical scavenging potential at $100 \mu \mathrm{g} / \mathrm{ml}$ (67.83 \& $65.54 \%$ respectively) as compared to Vit C (Table 2).

\begin{tabular}{|c|c|c|c|}
\hline \multicolumn{4}{|c|}{ Radical scavenging activity (\%) } \\
\hline PQQ \& Plant extracts & $\mathbf{2 5} \mathbf{\mu g} / \mathbf{m l}$ & $\mathbf{5 0} \mathbf{~} \mathbf{g} / \mathbf{m l}$ & $\mathbf{1 0 0} \mathbf{\mu g} / \mathbf{m l}$ \\
\hline WS & $36.39 \pm 0.34$ & $44.19 \pm 0.73$ & $48.07 \pm 0.33$ \\
\hline CM & $45.71 \pm 0.15$ & $52.72 \pm 0.21$ & $56.71 \pm 0.36$ \\
\hline RS & $47.3 \pm 0.09 \mathrm{y}$ & $51.3 \pm 0.09$ & $67.83 \pm 0.42^{\mathrm{x}}$ \\
\hline AS & $36.8 \pm 0.18$ & $44.73 \pm 0.21$ & $55.84 \pm 0.25$ \\
\hline SC & $38.86 \pm 0.25$ & $54.42 \pm 0.12$ & $65.54 \pm 0.08^{\mathrm{x}}$ \\
\hline GS & $37.9 \pm 0.11$ & $46.55 \pm 0.14$ & $51.33 \pm 0.08$ \\
\hline PQQ & $78.01 \pm 0.08^{\mathrm{x}}$ & $82.04 \pm 0.08^{\mathrm{x}}$ & $88.05 \pm 0.33^{\mathrm{x}}$ \\
\hline Vit.C & $45.97 \pm 0.15$ & $51.46 \pm 1.51$ & $58.12 \pm 0.07$ \\
\hline
\end{tabular}

Table 2: Radical scavenging activity (\%) in various plant extracts, Vit.C and PQQ observed by ABTS assay system.

WS,W. sominefera; CM,C. mukul; RS,R. serpentina; AS,A. squamosa; SC,S.cumini; GS, G. Sylvestre, PQQ, Pyrroloquinoline quinone ; Data are expressed in \% inhibition (mean \pm SE; $\mathrm{n}=3$ ). $x, \mathrm{P}<0.001 ; \mathrm{y}, \mathrm{P}<0.01$ and $\mathrm{z}, \mathrm{P}<0.05$ significantly more effective as compared to the respective concentration of Vit.C.

DPPH assay: In DPPH scavenging assay, all the studied doses of PQQ $(25,50$, and $100 \mu \mathrm{g} / \mathrm{ml})$ were found to be most effective (with a percent scavenging activity of 81.76, 88.21 and $91.69 \%$ respectively), PQQ significantly $(\mathrm{P}<0.001$ in all doses) exhibited better radical scavenging potential as compared to that of Vit.C. RS \& AS were found to show significant $(\mathrm{P}<0.001)$ higher radical scavenging potential at $100 \mu \mathrm{g} / \mathrm{ml}(81.54 \& 82.74 \%$ respectively) as compared to Vit.C (Table 3).

\begin{tabular}{|c|c|c|c|}
\hline \multicolumn{5}{|c|}{ Radical scavenging activity (\%) } \\
\hline PQQ \& Plant extracts & $\mathbf{2 5} \boldsymbol{\mu g} / \mathbf{m l}$ & $\mathbf{5 0} \boldsymbol{\mu \mathbf { g }} / \mathbf{m l}$ & $\mathbf{1 0 0} \mathbf{~} \mathbf{g} / \mathbf{m l}$ \\
\hline WS & $72.69 \pm 0.03$ & $77.41 \pm 0.19$ & $82.11 \pm 0.04^{\mathrm{x}}$ \\
\hline CM & $35.18 \pm 0.55$ & $51.23 \pm 1.05$ & $67.66 \pm 0.58$ \\
\hline RS & $72.45 \pm 0.28$ & $82.91 \pm 0.94^{\mathrm{z}}$ & $81.54 \pm 0.17^{\mathrm{z}}$ \\
\hline AS & $77.38 \pm 0.13$ & $79.21 \pm 0.49$ & $82.74 \pm 0.03^{\mathrm{x}}$ \\
\hline SC & $77.34 \pm 0.40$ & $77.07 \pm 0.19$ & $78.25 \pm 0.08$ \\
\hline GS & $75.43 \pm 0.06$ & $77.81 \pm 0.25$ & $80.75 \pm 0.21$ \\
\hline PQQ & $81.76 \pm 0.01^{\mathrm{x}}$ & $88.21 \pm 0.10^{\mathrm{x}}$ & $91.69 \pm 0.36^{\mathrm{x}}$ \\
\hline Vit.C & $76.52 \pm 0.22$ & $77.75 \pm 0.23$ & $80.47 \pm 0.06$ \\
\hline
\end{tabular}

Table 3: Radical scavenging activity (\%) in various plant extracts, Vit.C and PQQ observed by DPPH assay system.

ws,W. sominefera; CM,C. mukul; RS,R. serpentina; AS,A. squamosa; SC,S.cumini, GS,G. Sylvestre, PQQ Pyrroloquinoline quinone ; Data are expressed in \% inhibition (mean \pm SE; $\mathrm{n}=3$ ). $x, \mathrm{P}<0.001 ; \mathrm{y}, \mathrm{P}<0.01$ and $\mathrm{z}, \mathrm{P}<0.05$ significantly more effective as compared to the respective concentration of Vit.C.

Metal chelating assay: In metal chelating activity, again all different concentrations of PQQ $(25,50$, and $100 \mu \mathrm{g} / \mathrm{ml})$ showed a greater metal chelating activities $(43.68,48.66$ and $61.12 \%$, respectively), which are significantly $(\mathrm{P}<$
0.05; $\mathrm{P}<0.01 ; \mathrm{P}<0.001$ respectively) higher as compared to plant extracts and Vit.C. Of course no plant extract was found to exhibit better chelating activity as compared to Vit.C (Table 4). 


\section{Advances in Pharmacology and Clinical Trials}

ISSN: 2474-9214

\begin{tabular}{|c|c|c|c|}
\hline \multicolumn{4}{|c|}{ Radical scavenging activity } \\
\hline PQQ \& Plant extracts & $\mathbf{2 5} \boldsymbol{\mu g} / \mathbf{m l}$ & $\mathbf{5 0} \boldsymbol{\mu g} / \mathbf{m l}$ & $\mathbf{1 0 0} \boldsymbol{\mu g} / \mathbf{m l}$ \\
\hline WS & $39.11 \pm 0.01$ & $40.26 \pm 0.16$ & $41.79 \pm 0.05$ \\
\hline CM & $42.69 \pm 0.11$ & $42.19 \pm 0.03$ & $41.44 \pm 0.10$ \\
\hline RS & $25.46 \pm 0.17$ & $32.86 \pm 0.07$ & $38.17 \pm 0.11$ \\
\hline AS & $6.08 \pm 0.21$ & $8.35 \pm 0.26$ & $23.86 \pm 0.82$ \\
\hline SC & $7.8 \pm 0.07$ & $16.4 \pm 0.15$ & $29.66 \pm 0.12$ \\
\hline GS & $38.84 \pm 0.10$ & $35.68 \pm 0.15$ & $29.56 \pm 0.12$ \\
\hline PQQ & $43.68 \pm 0.19^{\mathrm{z}}$ & $48.66 \pm 0.18^{\mathrm{y}}$ & $61.12 \pm 0.11^{\mathrm{x}}$ \\
\hline Vit.C & $42.38 \pm 0.08$ & $42.55 \pm 0.07$ & $41.94 \pm 0.01$ \\
\hline
\end{tabular}

Table 4: Radical scavenging activity (\%) in various plant extracts, Vit. C and PQQ observed by metal chelating activity assay system.

WS,W. sominefera; CM,C. mukul; RS, R. serpentina; AS,A. squamosa; SC,S.cumini, GS, G. Sylvestre, PQQ, Pyrroloquinoline quinone; Data are expressed in \% inhibition (mean $\pm \mathrm{SE} ; \mathrm{n}=3$ ). $\mathrm{x}, \mathrm{P}<0.001 ; \mathrm{y}, \mathrm{P}<0.01$ and $\mathrm{z}, \mathrm{P}<0.05$ significantly more effective as compared to the respective concentration of Vit.C.

SO radical scavenging assay: In SO radical scavenging assay, $\mathrm{PQQ}$ in all tested doses $(25,50$, and $100 \mu \mathrm{g} / \mathrm{ml})$ was found to be effective to scavenge superoxide radicals significantly $(\mathrm{P}<0.001$ in all doses$)$ as compared to Vit.C, with a percent scavenging activity of $60.65,66.32$ and $72.14 \%$ respectively, while no plant extract was found to have better chelating activity as compared to Vit C (Table 5).

\begin{tabular}{|c|c|c|c|}
\hline \multicolumn{4}{|c|}{ Radical scavenging activity } \\
\hline PQQ \& Plant extracts & $\mathbf{2 5} \boldsymbol{\mu g} / \mathbf{m l}$ & $\mathbf{5 0} \boldsymbol{\mu} \mathbf{g} \mathbf{~ m l}$ & $\mathbf{1 0 0} \boldsymbol{\mu g} / \mathbf{m l}$ \\
\hline WS & $6.02 \pm 0.03$ & $12.52 \pm 0.06$ & $36.66 \pm 0.04$ \\
\hline CM & $9.01 \pm 0.02$ & $17.66 \pm 0.07$ & $37.78 \pm 0.57$ \\
\hline RS & $11.8 \pm 0.12^{\mathrm{x}}$ & $35.73 \pm 0.06^{\mathrm{x}}$ & $39.9 \pm 0.02$ \\
\hline AS & $14.85 \pm 0.04^{\mathrm{x}}$ & $32.74 \pm 0.04$ & $45 \pm 0.04$ \\
\hline SC & $11.68 \pm 0.07^{\mathrm{x}}$ & $39.28 \pm 0.09^{\mathrm{x}}$ & $47.99 \pm 0.03^{\mathrm{x}}$ \\
\hline GS & $37.22 \pm 0.57^{\mathrm{x}}$ & $47.56 \pm 0.21^{\mathrm{x}}$ & $54.34 \pm 0.03^{\mathrm{x}}$ \\
\hline PQQ & $17.66 \pm 0.07^{\mathrm{x}}$ & $39.84 \pm 0.04^{\mathrm{x}}$ & $63.31 \pm 0.05^{\mathrm{x}}$ \\
\hline Vit.C & $10.1 \pm 0.03$ & $32.8 \pm 0.05$ & $44.98 \pm 0.03$ \\
\hline
\end{tabular}

Table 5: Radical scavenging activity (\%) in various plant extracts, Vit.C and PQQ observed by $\mathrm{H}_{2} \mathrm{O}_{2}$ scavenging assay system.

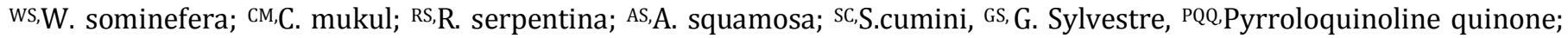
Data are expressed in \% inhibition (mean $\pm \mathrm{SE} ; \mathrm{n}=3$ ). $\mathrm{x}, \mathrm{P}<0.001 ; \mathrm{y}, \mathrm{P}<0.01$ and ${ }^{\mathrm{z}}, \mathrm{P}<0.05$ significantly more effective as compared to the respective concentration of Vit C.

$\mathrm{H}_{2} \mathrm{O}_{2}$ scavenging assay: In this assay, GS was found to be most effective in $\mathrm{H}_{2} \mathrm{O}_{2}$ scavenging activity at dose of 25 and $50 \mu \mathrm{g} / \mathrm{ml}$, as compared to PQQ and Vit C. However, at dose of $100 \mu \mathrm{g} / \mathrm{ml} \mathrm{PQQ}$ was again found to be most effective $(\mathrm{P}<0.001)$ to scavenge free radicals as compare to plant extracts and Vit C. While no plant extract was found to exhibit better chelating activity as compared to Vit C (Tables 6 and 7).

\begin{tabular}{|c|c|c|c|}
\hline \multicolumn{4}{|c|}{ Radical scavenging activity (\%) } \\
\hline PQQ \& Plant extracts & $\mathbf{2 5} \boldsymbol{\mu g} / \mathbf{m l}$ & $\mathbf{5 0} \boldsymbol{\mu g} / \mathbf{m l}$ & $\mathbf{1 0 0} \boldsymbol{\mu g} / \mathbf{m l}$ \\
\hline WS & $23.99 \pm 0.21$ & $31.24 \pm 0.02$ & $38.51 \pm 0.02$ \\
\hline CM & $28.41 \pm 0.09$ & $34.09 \pm 0.03$ & $42.98 \pm 0.02$ \\
\hline RS & $38.36 \pm 0.11$ & $46.68 \pm 0.15$ & $55.33 \pm 0.02$ \\
\hline
\end{tabular}




\section{Advances in Pharmacology and Clinical Trials}

\begin{tabular}{|c|c|c|c|}
\hline AS & $32.66 \pm 0.15$ & $38.45 \pm 0.03$ & $48.01 \pm 0.02$ \\
\hline SC & $39.53 \pm 0.12$ & $44.09 \pm 0.02$ & $50.36 \pm 0.03$ \\
\hline GS & $43.76 \pm 0.20$ & $51.26 \pm 0.04$ & $57.01 \pm 0.02$ \\
\hline PQQ & $60.65 \pm 0.15^{\mathrm{x}}$ & $66.32 \pm 0.06^{\mathrm{x}}$ & $72.14 \pm 0.02^{\mathrm{x}}$ \\
\hline Vit.C & $54.54 \pm 0.13$ & $62.35 \pm 0.10$ & $65.95 \pm 0.02$ \\
\hline
\end{tabular}

Table 6: Radical scavenging activity (\%) in various plant extracts, Vit.C and PQQ observed with by SO scavenging assay system.

WS,W. sominefera; $C M, C$. mukul; ${ }^{R S, R}$. serpentina; AS,A. squamosa; SC,S.cumini, GS, G. Sylvestre, PQQ.Pyrroloquinoline quinone; Data are expressed in \% inhibition (mean $\pm \mathrm{SE}$; $\mathrm{n}=3$ ). $\mathrm{x}, \mathrm{P}<0.001 ; \mathrm{y}, \mathrm{P}<0.01$ and ${ }^{\mathrm{z}}, \mathrm{P}<0.05$ significantly more effective as compared to the respective concentration of Vit.C.

\begin{tabular}{|c|c|c|c|c|c|}
\hline & ABTS & DPPH & $\mathbf{F e C l}_{\mathbf{2}}$ & SO & $\mathbf{H}_{\mathbf{2}} \mathbf{O}_{\mathbf{2}}$ \\
\hline WS & 39.79 & 38.76 & 38.25 & 42.03 & 54.14 \\
\hline CM & 39.38 & 43.5 & 37.14 & 42.02 & 53.33 \\
\hline RS & 42.27 & 37.92 & 40.09 & 41.13 & 43.12 \\
\hline AS & 41.92 & 38.32 & 52.97 & 41.71 & 45.37 \\
\hline SC & 41.97 & 37.72 & 48.89 & 40.16 & 44.63 \\
\hline GS & 40.06 & 38.25 & 33.96 & 39.97 & 40.78 \\
\hline PQQ & 38.89 & 38.51 & 41.62 & 39.3 & 47.4 \\
\hline Vit.C & 40 & 38.13 & 37.29 & 39.07 & 46.18 \\
\hline
\end{tabular}

Table 7: IC50 ( $\mu \mathrm{g} / \mathrm{ml})$ values of various plant extracts, Vit.C and PQQ in ABTS; DPPH; metal chelating, superoxide and hydrogen peroxide scavenging assay.

WS,W. sominefera; ${ }^{M}, C$. mukul; RS,R. serpentina; AS,A. squamosa; SC,S.cumini, GS, G. Sylvestre, PQQ Pyrroloquinoline quinone; Data are expressed in $\%$ inhibition (mean $\pm \mathrm{SE} ; \mathrm{n}=3$ ).

Thus the differential effects were found in PQQ and the test plant extracts. Interestingly $\mathrm{PQQ}$ exhibited better effects as compared to the plant extracts and the orders of the effects exerted by different plant extracts in different assay systems and in different concentrations were as follows:

\begin{tabular}{|c|c|c|}
\hline & \multicolumn{2}{|c|}{ ABTS scavenging assay: } \\
\hline & 25 нg/ml - & $\mathrm{PQQ}>\mathrm{RS}>$ Vit.C $>\mathrm{CM}>\mathrm{SC}>\mathrm{GS}>\mathrm{AS}>\mathrm{WS}$ \\
\hline & $50 \mu \mathrm{g} / \mathrm{ml}-$ & $\mathrm{PQQ}>\mathrm{SC}>\mathrm{CM}>$ Vit.C $>\mathrm{RS}>\mathrm{GS}>\mathrm{AS}>\mathrm{WS}$ \\
\hline & $100 \mu \mathrm{g} / \mathrm{ml}-$ & $\mathrm{PQQ}>\mathrm{RS}>\mathrm{SC}>$ Vit.C $>\mathrm{CM}>\mathrm{AS}>\mathrm{GS}>\mathrm{WS}$ \\
\hline \multirow[t]{4}{*}{$>$} & \multicolumn{2}{|c|}{ DPPH scavenging assay: } \\
\hline & 25 нg/ml - & $\mathrm{PQQ}>\mathrm{SC}>\mathrm{AS}>$ Vit. $\mathrm{C}>\mathrm{GS}>\mathrm{WS}>\mathrm{RS}>\mathrm{CM}$ \\
\hline & $50 \mu \mathrm{g} / \mathrm{ml}-$ & $\mathrm{PQQ}>\mathrm{RS}>\mathrm{AS}>\mathrm{GS}>$ Vit. $\mathrm{C}>\mathrm{SC}>\mathrm{WS}>\mathrm{CM}$ \\
\hline & $100 \mu \mathrm{g} / \mathrm{ml}-$ & $\mathrm{PQQ}>\mathrm{AS}>\mathrm{WS}>\mathrm{RS}>\mathrm{GS}>$ Vit.C $>\mathrm{SC}>\mathrm{CM}$ \\
\hline \multirow[t]{4}{*}{$\theta$} & \multicolumn{2}{|c|}{ Metal chelating activity: } \\
\hline & 25 нg/ml - & $\mathrm{PQQ}>\mathrm{CM}>$ Vit. $\mathrm{C}>\mathrm{WS}>\mathrm{GS}>\mathrm{RS}>\mathrm{SC}>\mathrm{AS}$ \\
\hline & $50 \mu \mathrm{g} / \mathrm{ml}-$ & $\mathrm{PQQ}>$ Vit.C $>\mathrm{CM}>\mathrm{WS}>\mathrm{GS}>\mathrm{RS}>\mathrm{SC}>\mathrm{AS}$ \\
\hline & $100 \mu \mathrm{g} / \mathrm{ml}-$ & $\mathrm{PQQ}>$ Vit.C $>\mathrm{WS}>\mathrm{CM}>\mathrm{RS}>\mathrm{SC}>\mathrm{GS}>\mathrm{AS}$ \\
\hline & \multicolumn{2}{|c|}{ Superoxide radical scavenging assay: } \\
\hline & 25 нg/ml - & $\mathrm{PQQ}>$ Vit.C $>\mathrm{GS}>\mathrm{AS}>\mathrm{SC}>\mathrm{RS}>\mathrm{CM}>\mathrm{WS}$ \\
\hline & $50 \mu \mathrm{g} / \mathrm{ml}-$ & $\mathrm{PQQ}>$ Vit.C $>\mathrm{GS}>\mathrm{RS}>\mathrm{SC}>\mathrm{AS}>\mathrm{CM}>\mathrm{WS}$ \\
\hline & $100 \mu \mathrm{g} / \mathrm{ml}-$ & $\mathrm{PQQ}>$ Vit.C $>\mathrm{GS}>\mathrm{RS}>\mathrm{SC}>\mathrm{AS}>\mathrm{CM}>\mathrm{WS}$ \\
\hline & \multicolumn{2}{|c|}{$\mathrm{H}_{2} \mathrm{O}_{2}$ scavenging assay: } \\
\hline & $25 \mu \mathrm{g} / \mathrm{ml}-$ & $\mathrm{GS}>\mathrm{PQQ}>\mathrm{AS}>\mathrm{RS}$ \\
\hline & $50 \mu \mathrm{g} / \mathrm{ml}-$ & $>\mathrm{PQQ}>\mathrm{SC}>\mathrm{RS}>$ Vit.C $>\mathrm{AS}>$ \\
\hline & & Q $>$ GS $>$ SC $>$ Vit.C $>$ AS $>$ RS $>$ CM $>$ WS \\
\hline
\end{tabular}

Kumar N and Kar A. Comparative Analysis of Free Radical Scavenging Potential of Pyrroloquinoline Quinone (PQQ) and Several Plants Extracts by 


\section{Advances in Pharmacology and Clinical Trials}

\section{Discussion}

From the results it was revealed that hepatic lipid peroxidation was inhibited by the test compound, PQQ at one /or the other doses, indicating its antiperoxidative nature. However, the percent inhibition was dependent on the type of chemical oxidant, used for the induction of peroxidation process.

Following the addition of different types of LPO inducing chemicals, there was a marked induction in the LPO. Interestingly, when the oxidant was incubated with PQQ, concentration dependent effects were observed, as PQQ inhibited $\mathrm{FeSO}_{4} / \mathrm{CCl}_{4} / \mathrm{H}_{2} \mathrm{O}_{2}$-induced hepatic LPO. Infact, after incubating liver homogenates with prestandardized concentrations of $\mathrm{FeSO}_{4}(5 \mathrm{mM}), \mathrm{CCl}_{4}(20 \mu \mathrm{l})$ and $\mathrm{H}_{2} \mathrm{O}_{2}(80 \mathrm{mM})$ along with PQQ, LPO was decreased in all the tubes. Although, out of five different concentrations of PQQ, only $20 \mu \mathrm{M}, 80 \mu \mathrm{M}$ and $80 \mu \mathrm{M}$ were found to inhibit maximally the $\mathrm{FeSO}_{4} / \mathrm{CCl}_{4} / \mathrm{H}_{2} \mathrm{O}_{2}$-induced tissue LPO respectively, PQQ exhibited its antioxidative effects all the time.

As $\mathrm{FeSO}_{4}$-induced LPO is known to take place through ferryl perferryl complex [28] and PQQ inhibited the $\mathrm{FeSO}_{4}$-induced LPO in a dose dependent manner, it appears that the process was mediated through an inhibition of ferryl per-ferryl complex formation. It is also possibile that the total amount of ferrous ions available for LPO stimulation might have been partly reduced by PQQ to the forms that do not stimulate LPO.

The addition of $\mathrm{H}_{2} \mathrm{O}_{2}$ and $\mathrm{CCl}_{4}$ also increased LPO significantly as observed earlier by other workers [9,11,28-30]. Interestingly, in these cases also the chemical-induced LPO was inhibited by PQQ again supporting its antiperoxidative nature. $\mathrm{H}_{2} \mathrm{O}_{2}$, a nonradical reactive oxygen species, considered as the most stable intermediate easily passes through cell membranes by diffusion and inside the cell it reacts with transition metals liberating hydroxyl radicals [31], which in turn, induce peroxidation of lipids and proteins, affecting cell integrity [31,32]. Probably in the present study an inhibition in $\mathrm{H}_{2} \mathrm{O}_{2}$-induced LPO by PQQ might have been mediated through the inhibition in $\mathrm{OH}$ radicals.

$\mathrm{CCl}_{4}$-induced hepatic LPO was also inhibited by PQQ, further supporting its antiperoxidative potential. $\mathrm{CCl}_{4}$ is believed to be metabolized by cytochrome $\mathrm{P}_{450}$ present in the microsomal and nuclear membranes [21,33] and high concentration of this compound inhibits the functional oxidase system and always induces LPO. As the reactive metabolite inducing LPO is believed to be the trichloromethyl radical that alters membrane function by blocking ion pumps within the cell [21], in our study also it appears that the PQQ inhibiting LPO might have been brought either through enhancing cytochrome $\mathrm{P}_{450}$ enzymes or through an inhibition in trichloromethyl radicals.

Our findings for the first time reveal that PQQ has the potential to ameliorate chemical induced hepatic LPO in three in-vitro systems. In fact, the radical scavenging capability of phenolic/ quinone compounds are due to their hydrogen donating ability or due to the number of hydroxyl groups present, which in turn modify the reactivity of the molecules [34-35].

In the present study the antiperoxidative role of PQQ is supported by the results of different antioxidant potential assays and is also compared to the some plant extracts and vitamin $\mathrm{C}$, which are well known for their antioxidative nature [7,36]. In ABTS radical scavenging activity, the antioxidant capacity of PQQ, Vit.C and different plant extracts were evaluated according to the ABTS decolorization method. The results of antioxidant activity of all samples as expressed in percentage inhibition indicated that the PQQ displayed the highest radical scavenging potential in all doses as compared to Vit.C and all plant extracts, thus consolidating its better antioxidant potential as compared to Vit.C.

Somewhat similar findings were made with respect to scavenging the stable DPPH radical, a widely used method to evaluate the free radical scavenging ability of various samples [24]; DPPH is a stable nitrogen-centered free radical, the color of which changes from violet to yellow upon reduction by either the process of hydrogen- or electron- donation. Substances which are able to perform this reaction can be considered as antioxidants and therefore radical scavengers [37]. Results of this study further confirmed that PQQ has high radical-scavenging activities with all doses as compared to Vit.C and all the test plant extracts.

Iron generates LPO by accelerating the dissociation of lipid hydroperoxides to their respective peroxy and alkoxy radicals [38]. In our study iron chelating percentage was highest for PQQ and it increased with increase in concentration. PQQ also showed higher metal chelating activity as compared to Vit.C and plant extracts (Table 4). These effects could be due to the presence of polyphenols which has potent iron chelating capacity. The reducing power of a PQQ is related to its electron transfer ability and may serve as a significant indicator of its potential antioxidant activity. With respect to superoxide 


\section{Advances in Pharmacology and Clinical Trials}

scavenging activity, it was observed that PQQ possesses better dose dependent superoxide scavenging potential than Vit.C and plant extracts. Probably this higher scavenging activity of $\mathrm{PQQ}$ is due to its high redox potential with hydroxyl group $(\mathrm{O}-\mathrm{H})$ that is easily liberated for stabilization of superoxide anion.

Hydrogen peroxide can cross cell membranes rapidly, once inside the cell, $\mathrm{H}_{2} \mathrm{O}_{2}$ may react with $\mathrm{Fe}^{2+}$, and possibly $\mathrm{Cu}^{2+}$ ions to form hydroxyl radical and this may be the origin of many of its toxic effects [39]. Although GS extract showed better hydrogen peroxide scavenging activity at 25 and $50 \mu \mathrm{g} / \mathrm{ml}$. At higher dose of PQQ appeared to be better than rest of all plant extracts and Vit.C. Whatever may be the mode of action(s), our findings clearly indicate that the antioxidative property of $P Q Q$ is better than the tested antioxidative plant extracts or Vit. $C$, suggesting that $P Q Q$ may prove to be beneficial to diseases associated with LPO. In conclusion, for the first time ameliorating effects of $\mathrm{PQQ}$ in the chemically $\left(\mathrm{FeSO}_{4} / \mathrm{CCl}_{4} / \mathrm{H}_{2} \mathrm{O}_{2}\right)$-induced in vitro LPO in hepatic tissue were evaluated. It is also emphasized that, as compared free radical scavenging potential of PQQ to some plant extracts, it contains higher antioxidative activities. Therefore, we suggest that the PQQ may be further studied to explore its therapeutic potential in treating different chronic diseases that are associated with LPO.

\section{Acknowledgement}

Financial support from the Council of Scientific and Industrial Research (CSIR), New Delhi, India. Ref. No. 09/301/(0121)/2011-EMR I for a Senior Research fellowship to Narendra Kumar is gratefully acknowledged.

\section{Conflict of Interest}

Authors do not have any conflict of interest.

\section{References}

1. Pryor WA (1973) Free radical reactions and their importance in biochemical systems. Fed Proc 32(8): 1862-1869.

2. Fantone JC, Ward PA (1982) Role of oxygen-derived free radicals and metabolites in leukocyte-dependent inflammatory reactions. Am J Pathol 107(3): 395-418.

3. Fejes SZ, Blázovics A, Lemberkovics E, Petri G, Szöke E, et al. (2000) Free radical scavenging and membrane protective effects of methanol extracts from Anthriscus cerefolium L. (Hoffm.) and Petroselinum crispum (Mill.) Nym. ex W Hill Phytother Res 14(5): 362-365.

4. Kim YK, Guo Q Packer L (2002) Free radical scavenging activity of red ginseng aqueous extracts. Toxicology 172(2): 149-156.

5. Velazquez E, Tournier HA, Mordujovich de B (2003) Antioxidant potential of Paraguayan plant extracts. Fitoterapia 74(1-2): 91-97.

6. Kar A, Panda S (2004) Ayurvedic therapies for thyroid dysfunction. In: Mishra L, ed. Scientific basis of ayurvedic therapies. CRC press, USA, Chapter 8.

7. Sharma N, Kar A, Panda S (2015) Administration of fenugreek seed extract produces better effects in the glibenclamide-induced inhibition in hepatic lipid peroxidation: An in vitro study. Chin J Integr Med 110.

8. Ho SC, Lin CC (2008) Investigation of heat treating conditions for enhancing the anti-inflammatory activity of citrus fruit (Citrus reticulata) peels. J Agric Food Chem 56(17): 7976-7982.

9. Parmar HS, Kar A (2008a) Antiperoxidative, antithyroidal antihyperglycemic and cardioprotective role of Citrus sinensis peel extract in male mice. Phytother Res 22(6): 791-795.

10. Parmar HS, Kar A (2008b) Medicinal values of fruit peels from Citrus sinensis, Punica granatum, and Musa paradisiaca with respect to alterations in tissue lipid peroxidation and serum concentration of glucose, insulin, and thyroid hormones. J Med Food 11(2): 376-381.

11. Dixit Y, Kar A (2009) Antioxidative activity of some vegetable peels determined in vitro by inducing liver lipid peroxidation. Food Res Int 42(9): 1351-1354.

12. Braughler JM, Duncan LA, Chase RL (1986) The involvement of iron in LPO. Journal of Biological Chemistry 261: 10282-10289.

13. Slater TF, Sawyer BC (1971) The stimulatory effect of $\mathrm{CCl}_{4}$ and other halogenoalkanes on peroxidative reactions in rat liver fractions in vitro. General features of the systems used. The Biochemical Journal 123: 805-814. 


\section{Advances in Pharmacology and Clinical Trials}

14. Stocks J, Offerman EL, Modell CB, Dormandy TL (1972) The susceptibility to autoxidation of human red cells lipids in health and disease. Br J Hematol 23(6): 713-724.

15. Rastogi RP, Mehrotra BN (1994) In Comp. of Indian medicinal plants 5: 715-716.

16. Campos R, Garrido A, Guerra R, Valenzyela A (1989) Silybin dihemisuccinate protects against glutathione depletion and lipid peroxidation induced by acetaminophen on rat liver. Planta Med 55(5): 417419.

17. Sharma M, Tripathi P, Singh VP, Tripathi YB (1995) Hepatoprotective and toxicological evaluation of hepatomed, an ayurvedic drug. Indian J Exp Biol 33(1): 34-37.

18. Tripathi YB, Chaurasia S, Tripathi E, Upadhyay A, Dubey GP (1996) Bacopa monniera Linn. as an antioxidant: Mechanism of action. Indian J Exp Biol 34(6): 523-526.

19. Ohkawa H, Ohishi N, Yagi K (1979) Assays of lipid peroxides in animal tissues by thiobarbituric acid reaction. Anal Biochem 95(2): 351-358.

20. Lutz LM, Glende EA Jr, Recknagel RO (1973) Protection by diethyl dithio carbamate against carbon tetra chloride lethality in rats and against carbon tetrachloride induced LPO in vitro. Biochemistry and Pharmacology 22(14): 1729-1734.

21. Arnao M, Cano A, Acosta M (2001) The hydrophilic and lipophilic contribution to total antioxidant activity. Food Chem 73: 239-244.

22. Yamaguchi T, Takamura H, Matoba T, Terao J (1998) HPLC method for evaluation of the free radicalscavenging activity of foods by using 1,1,-diphenyl-2picrylhydrazyl. Biosci Biotechnol Biochem 62(6): 1201-1204.

23. Ebrahimzadeh MA, Pourmorad F, Hafezi S (2008) Antioxidant activities of Iranian corn silk, Turk. J Biol 32(1): 43-49.

24. Ruch RJ, Cheng SJ, Klaunig JE (1989) Prevention of cytotoxicity and inhibition of intracellular communication by antioxidant catechins isolated from Chinese green tea. Carcinogenesis 10(6): 10031008.
25. Liu F, Ooi VEC, Chang ST (1997) Free radical scavenging activity of mushroom polysaccharide extracts. Life Sci 60(10): 763-771.

26. Gutteridge JM (1985) Age pigments and free radicals: Fluorescent lipid complexes formed by iron- and copper-containing proteins. Biochimica Biophysica Acta 834(2): 144-148.

27. Recknagel RO (1967) Carbon tetrachloride hepatotoxicity. Pharmacological Revision 19(2): 145208.

28. Kostyuk VA, Potapovich AI (1991) Damage of rat liver microsomal mixed function oxidase system by carbon tetrachloride. In vivo study with selective inhibitor of lipid peroxidation. Biochemistry International 25(2): 349-353.

29. Jung TY, Suh SI, Lee H, Kim IS, Kim HJ, et al. (2007) Protective effects of several components of gastrodia elata on lipid peroxidation in gerbil brain homogenates. Phytother Res 21(10): 960-964.

30. Abele OD, Sartoris FJ, Portner HO (1997) Hydrogen peroxide causes a decrease in aerobic metabolic rate and in intracellular $\mathrm{pH}$ in the shrimp Crangon crangon. Comp Biochem Physiol 117(2): 123-129.

31. Halliwel B, Gutteridge JMC (1995) The definition and measurement of antioxidants in biological systems. Free Radic Biol Med 18(1): 125-126.

32. DiazGomez MI, Castro JA (1980) Covalent binding of carbon tetrachloride metabolites to liver nuclear DNA, proteins, and lipids. Toxicol Appl Pharmacol 56(2): 199-206.

33. Ariga T, Hamano M (1990) Radical scavenging actions and its mode in procyanidins B1 and B3 from azuki beans to peroxy radicals. Agricultural and Biological Chemistry 54(10): 2499-2504.

34. Chen CW, Ho CT (1995) Antioxidant properties of polyphenols extracted from green and black tea. Journal of Food Lipids 2(1): 35-46.

35. Panda S, Kar A (2000) How safe is neem extract with respect to thyroid function in male mice. Pharmacol res 41(4): 419-422. 


\section{Advances in Pharmacology and Clinical Trials}

36. Dehpour AA, Ebrahimzadeh MA, Nabavi SF, Nabavi SM (2009) Antioxidant activity of methanol extract of Ferula assafoetida and its essential oil composition. Grasas Aceites 60(4): 405-412.

37. Dinis TCP, Maderia VM, Almeida LM (1994) Action of phenolic derivatives (acetaminophen, salicylate, and 5-aminosalicylate) as inhibitors of membrane lipid peroxidation and as peroxy radical scavengers. Arch Biochem Biophys 315(1): 161-169.
38. Nabavi SM, Ebrahimzadeh MA, Nabavi SF, Hamidinia, A, Bekhradnia AR (2008a) Determination of antioxidant activity, phenol and flavonoids content of Parrotia persica Mey. Pharmacology online 2: 560567

39. Nabavi SM, Ebrahimzadeh MA, Nabavi SF and Bahramian F (2009b) In vitro antioxidant activity of Phytolacca americana berries. Pharmacologyonline 1 : 81-88. 